\title{
Above- and belowground tree biomass models for three mangrove species in Tanzania: a nonlinear mixed effects modelling approach
}

\author{
Marco Andrew Njana ${ }^{1}$ • Ole Martin Bollandsås ${ }^{2} \cdot$ Tron Eid $^{2} \cdot$ Eliakimu Zahabu $^{1}$ • \\ Rogers Ernest Malimbwi ${ }^{1}$
}

Received: 23 April 2015 / Accepted: 18 September 2015 / Published online: 14 October 2015

(C) INRA and Springer-Verlag France 2015

\begin{abstract}
- Key message Tested on data from Tanzania, both existing species-specific and common biomass models developed elsewhere revealed statistically significant large prediction errors. Species-specific and common above- and belowground biomass models for three mangrove species were therefore developed. The species-specific models fitted better to data than the common models. The former models are recommended for accurate estimation of biomass stored in mangrove forests of Tanzania.

- Context Mangroves are essential for climate change mitigation through carbon storage and sequestration. Biomass models are important tools for quantifying biomass and carbon stock. While numerous aboveground biomass models
\end{abstract}

Handling Editor: Shuqing Zhao

Contribution of co-authors: Njana: Took part in design of research, responsible for data collection and preparation, and for data analysis and manuscript development.

O. M. Bollandsås: Supervising the work including providing technical guidance on data analysis and commenting on the manuscript.

T. Eid: Took part in design of the research, supervising the work, commenting, and manuscript development.

E. Zahabu: Supervising the work and commenting on the manuscript.

R. Malimbwi: Coordinating the design of research project and commenting on the manuscript.

Marco Andrew Njana

marconjana2002@yahoo.com

Ole Martin Bollandsås

ole.martin.bollandsas@nmbu.no

Tron Eid

tron.eid@nmbu.no

Eliakimu Zahabu

zahabue@yahoo.com exist, very few studies have focused on belowground biomass, and among these, mangroves of Africa are hardly or not represented.

- Aims The aims of the study were to develop above- and belowground biomass models and to evaluate the predictive accuracy of existing aboveground biomass models developed for mangroves in other regions and neighboring countries when applied on data from Tanzania.

- Methods Data was collected through destructive sampling of 120 trees (aboveground biomass), among these 30 trees were sampled for belowground biomass. The data originated from four sites along the Tanzanian coastline covering three dominant species: Avicennia marina (Forssk.) Vierh, Sonneratia alba J. Smith, and Rhizophora mucronata Lam. The biomass models were developed through mixed modelling leading to fixed effects/common models and random effects/speciesspecific models.

- Results Both the above- and belowground biomass models improved when random effects (species) were considered. Inclusion of total tree height as predictor variable, in addition to diameter at breast height alone, further improved the model predictive accuracy. The tests of existing models from other regions on our data generally showed large and significant prediction errors for aboveground tree biomass.

Rogers Ernest Malimbwi remalimbwi@yahoo.com

1 Department of Forest Mensuration and Management, Sokoine University of Agriculture, P.O. Box 3013, Morogoro, Tanzania

Department of Ecology and Natural Resources Management, Norwegian University of Life Sciences, Ås, Norway 
- Conclusion Inclusion of random effects resulted into improved goodness of fit for both above- and belowground biomass models. Species-specific models therefore are recommended for accurate biomass estimation of mangrove forests in Tanzania for both management and ecological applications. For belowground biomass ( $S$. alba) however, the fixed effects/common model is recommended.

Keywords Avicennia-Sonneratia-Rhizophora · Carbon . Fixed and random effects

\section{Introduction}

Mangroves are forests found in the tropical and subtropical coastlines between $30^{\circ}$ south and north of equator (FAO 2007). In Africa, there are mangroves both at the western and eastern coasts. At the eastern coast of Africa, 14 mangrove species are growing naturally, and 10 among these are found in Tanzania. Avicennia marina (Forssk.) Vierh, Sonneratia alba J. Smith, and Rhizophora mucronata Lam. are the three most dominant mangrove species in Tanzania (MNRT 1991; Luoga et al. 2004; Nshare et al. 2007).

Mangroves provide a range of goods and services of biological and economic importance. In addition, mangroves store large amounts of carbon per unit area (Donato et al. 2011; Murray et al. 2011) and are therefore also important for climate change mitigation (UNEP 2014). Although mangroves in many countries are legally protected, for example in Tanzania, Kenya, and South Africa (FAO 2007), mangroves suffer from deforestation and forest degradation (Wang et al. 2003).

A climate change mitigation strategy under the United Nations Framework Convention on Climate Change (UNFCCC), aiming at Reducing Carbon Emissions from Deforestation and Forest Degradation (REDD+), offers an opportunity for conservation and management of mangroves. Successful implementation of REDD+ relies on the capabilities of participating countries to routinely and reliably monitor changes of carbon stocks and associated greenhouse gas emissions through establishment of a Monitoring, Reporting and Verification (MRV) system (Hewson et al. 2013). In line with this, Tanzania has, under the National Forestry Resources Monitoring and Assessment (NAFORMA) program, established a national grid of permanent sample plots, which will be monitored for biomass and carbon over time (URT 2010). For Tanzania to be able to report carbon stocks at tier 2 or 3 (IPCC 2003), the development of country-specific biomass models is therefore imperative.
Biomass models, based on allometric theory, relating easily measurable tree variables such as diameter at breast height (dbh) and total tree height (ht) to biomass, are considered to be the most efficient tools for tree level biomass prediction (Brown 1997; IPCC 2007; Chave et al. 2014). The tree variables used as model input are obtained through forest inventories (Husch et al. 2003; URT 2010). Development of biomass models requires destructive sampling of trees. Above- and belowground fresh weights of the trees are measured in field, and subsequently, dry weights are determined by using the dry to fresh weight ratio (DF ratio) derived from ovendried subsamples. Aboveground biomass usually refers to stem, branch, and foliage, while belowground biomass refers to all live roots down to $2 \mathrm{~mm}$ in diameter (IPCC 2006).

Many models for prediction of both above- and belowground biomass of mangrove forests have been developed previously. A review by Komiyama et al. (2008) identified 13 species-specific and two common (i.e., multi-species) models for prediction of aboveground biomass of mangroves, while nine speciesspecific models and one common model were identified for belowground biomass. Additional studies on mangroves that developed models for prediction of biomass not present in this review also exist (e.g., Kairo et al. 2009; Kauffman and Donato 2012; Sitoe et al. 2014). With the exception of the models developed by Kairo et al. (2009) in Kenya and Sitoe et al. (2014) in Mozambique, most of the models have been developed for mangroves in Asia. The relatively few existing models for belowground biomass may be associated with the labor-intensive nature of sampling belowground biomass for mangrove tree species (Njana et al. 2015).

No biomass models have been developed for mangroves of Tanzania, yet numerous models have been developed based on data from other regions and some from neighboring countries in Africa. If these models are applied to quantify biomass of mangroves in Tanzania, they would be used beyond their spatial validity. Since mangrove trees may respond differently to different environmental conditions, this could also result into morphological and architectural differences between trees originating from different sites. Furthermore, it is also important that models are used within valid ranges in terms of species and tree size (dbh and ht). Models calibrated on data from other regions are more likely to violate these requirements. For example, the aboveground model by Chave et al. (2005) is based on mangrove data from a limited geographical area (French Guiana and Guadeloupe); thus, the model does not represent mangroves found in Africa and it does not include any dominant species found in Africa. Similarly, 
the aboveground biomass models from mangroves in Kenya and Mozambique are both based on data from one site, and they have limited sample size (e.g., $n=5$, Kairo et al. 2009; $n=31$ for six species, Sitoe et al. 2014) and tree size ranges (dbh up to $42 \mathrm{~cm}$, Sitoe et al. 2014). Trees with $\mathrm{dbh}>40 \mathrm{~cm}$ are likely to be found in Tanzania (e.g. Mattia, 1997). Therefore, if such models are applied in Tanzania, they are likely to provide biased estimates since the tree sizes are beyond size range of the model data.

Even though models should in principle not be used outside their geographical area and tree size ranges, this is sometimes necessary due to lack of local models. However, if no suitable data exist for testing, the user remains unaware of the nature of the prediction errors. Thus, model tests on real data are preferable, but this is of course seldom possible since suitable data would mostly be collected for calibrating local models, which renders the use of the alien model unnecessary. However, Njana et al. (2015) tested selected existing belowground biomass models on relevant data from Tanzania, both common (Komiyama et al. 2005) and species-specific (Tamai et al. 1986; Comley and McGuinness 2005; Kairo et al. 2009). The results revealed large prediction errors for both the common $(26-63 \%)$ and species-specific (55-63\%) models. These results support the development of new biomass models for Tanzanian mangrove forests.

The main objective of this study was therefore to develop tree biomass prediction models for the dominant mangrove species in Tanzania. Specifically, the study aimed to (1) provide basic information on the distribution of biomass between tree components and the rootto-shoot ratio, (2) develop both common and speciesspecific models for above- and belowground biomass, (3) develop models for aboveground biomass components (stem, branch, leaf, and twig), and (4) assess the predictive accuracy of the existing models and of those developed here in predicting the aboveground biomass of mangroves. A mixed modelling approach was applied.

\section{Materials and methods}

\subsection{Study area}

In Tanzania, mangroves grow naturally along the coastline between the borders to Kenya in the north and Mozambique in the south. Mangroves cover about 158,100 ha of Tanzania (MNRT 2015) and include 10 different species, namely A. marina, Bruguiera gymnorhiza, Ceriops tagal (Perr.) C. B. Rob., Heritiera littoralis Dryand., Lumnitzera racemosa Willd., Pemphis acidula J.R. \& G. Forst., R. mucronata,
S. alba, Xylocarpus granatum Koen., and Xylocarpus moluccensis (Lamk.) Roem. These species are also found in Kenya and Mozambique (Tamooh et al. 2008; Fatoyinbo et al. 2008; Mohamed et al. 2009). All mangroves in Tanzania are declared as forest reserves and managed by the Tanzania Forest Service Agency under the Ministry of Natural Resources and Tourism (URT 2002). The study was carried out at four sites: Pangani, Bagamoyo, Rufiji, and LindiMtwara (Table 1) covering the northern, middle, and southern parts of the costal belt of Tanzania.

\subsection{Tree sampling and measurement procedures}

Site conditions in mangrove forests usually vary perpendicular to the shorelines of the sea/rivers. To cover as much variation as possible, we established nested sample plots of 2- and $10-\mathrm{m}$ radii along 37 transects running from the shorelines across the entire extension of the mangrove vegetation. For each transect, the first plot was located close to the shoreline, while the remaining plots were located at distances varying from 150 to $250 \mathrm{~m}$ depending on the total extension of the mangroves. For some transects, it was not possible to establish all plots because of impenetrable mangrove vegetation or inaccessibility due to rivers/streams. Therefore, the number of plots sampled within transects varied from one to four. In total, we measured 120 plots. Fifteen plots were measured in Pangani and LindiMtwara, respectively, while 45 plots were measured in Bagamoyo and Rufiji, respectively (Njana et al. 2015).

Within 2-m radius of each plot, we measured dbh for all trees with $\mathrm{dbh} \geq 1 \mathrm{~cm}$ and total tree height $\geq 2 \mathrm{~m}$, while within $10-\mathrm{m}$ radius, we measured $\mathrm{dbh}$ for all trees with $\mathrm{dbh} \geq 5 \mathrm{~cm}$. For $A$. marina and $S$. alba trees, dbh was measured at $1.3 \mathrm{~m}$ above soil surface, while for R. mucronata trees, dbh was measured at $0.3 \mathrm{~m}$ above the highest stilt root.

In each plot, one tree was selected subjectively for destructive sampling, while ensuring an adequate representation of all the three species across sites, and diameter ranges from the sample plot. In total, 120 trees were sampled for aboveground biomass (40 for each of the three species), and among these, 30 were sampled for belowground biomass (10 for each of the three species). Among the sites, 15 trees (five for each species) were sampled in Pangani and Lindi-Mtwara, respectively, while 45 trees (15 for each species) were sampled in Bagamoyo and Rufiji, respectively (Njana et al. 2015). One S. alba sample tree had hollow and sandy sections, and since our focus was to develop models predicting biomass of healthy mangrove trees, this tree was excluded during modelling. 
Table 1 Site, location, dominant soil type, temperature, and precipitation for the study sites

\begin{tabular}{llll}
\hline Site and location & Dominant soil type & $\begin{array}{l}\text { Annual temperature }\left({ }^{\circ} \mathrm{C}\right) \\
\text { Mean } \pm \text { STD }\end{array}$ & $\begin{array}{c}\text { Annual rainfall (mm) } \\
\text { Mean } \pm \text { STD }\end{array}$ \\
\hline Pangani $\left(5^{\circ} 38^{\prime} \mathrm{S}, 38^{\circ} 54^{\prime} \mathrm{E}-5^{\circ} 40^{\prime} \mathrm{S}, 38^{\circ} 53^{\prime} \mathrm{E}\right)$ & Alluvial, clay, and sandy soils & $26.6 \pm 0.4$ & $1,240 \pm 333$ \\
Bagamoyo $\left(6^{\circ} 20^{\prime} \mathrm{S}, 38^{\circ} 50^{\prime} \mathrm{E}-6^{\circ} 33^{\prime} \mathrm{S}, 39^{\circ} 06^{\prime} \mathrm{E}\right)$ & Alluvial and sandy soils & $26.1 \pm 0.6$ & $940 \pm 239$ \\
Rufiji $\left(7^{\circ} 38^{\prime} \mathrm{S}, 39^{\circ} 16^{\prime} \mathrm{E}-7^{\circ} 55^{\prime} \mathrm{S}, 39^{\circ} 24^{\prime} \mathrm{E}\right)$ & Alluvial, silt, and clay soils & $27.0 \pm 0.3$ & $879 \pm 200$ \\
Lindi-Mtwara $\left(10^{\circ} 02^{\prime} \mathrm{S}, 39^{\circ} 39^{\prime} \mathrm{E}-10^{\circ} 15^{\prime} \mathrm{S}, 40^{\circ} 10^{\prime} \mathrm{E}\right)$ & Alluvial and sandy soils & $25.7 \pm 0.4$ & $1,072 \pm 249$
\end{tabular}

Source: Tanzania Meteorological Agency, rainfall and temperature data; Pangani and Lindi-Mtwara (1970-2012); Bagamoyo (1964-2013) and Rufiji (2005-2012)

Before the sample trees were cut, we measured dbh, basal diameter (bd, diameter $15 \mathrm{~cm}$ above ground level for A. marina and $S$. alba or immediately above the highest stilt root for $R$. mucronata) using a diameter tape. We also measured ht, crown diameter (crd), and bole height (bht, height from ground level to first branch) (Fig. 1). Total and bole tree height was determined using a Suunto hypsometer. Crown length (crl) was determined from the difference between ht and bole height.

Three $R$. mucronata sample trees were multi-stemmed. For these trees, diameters of individual stems $\left(\mathrm{dbh}_{i}\right)$ were combined and a surrogate for $\mathrm{dbh}$ was determined as $\mathrm{dbh}=$ $\sqrt{\sum \mathrm{dbh}_{i}^{2}}$ (e.g., Zhou et al. 2007) while we used the heights of individual stems to determine basal area-weighted mean heights that were used as surrogate for ht. Table 2 summarizes statistics for plot (i.e., for trees $\geq 5 \mathrm{~cm}$ ) and sample tree variables.

Using a chainsaw, trees were cut $15 \mathrm{~cm}$ above ground level for $A$. marina and $S$. alba, while $R$. mucronata trees were cut immediately above the highest stilt root (URT 2010) (see
Fig. 1). After felling, the aboveground part for tree with $\mathrm{dbh} \geq 15 \mathrm{~cm}$ was partitioned into (i) stem, (ii) branch ( $\geq 5 \mathrm{~cm}$ ), and (iii) twig and leaf, and among these, 10 trees for each of the three species were further partitioned into twig and leaf. Stem and branch were cross-cut into billets and their corresponding fresh weights determined using a spring balance measuring weight to the nearest $0.1 \mathrm{~kg}$. Fresh weights of small trees $(<5 \mathrm{~cm})$ were determined using a digital balance. Saw dusts from the chainsaw were not included in the fresh weight. For the large trees partitioned into twig and leaf, fresh weights were determined separately for each component. For all other trees, the aggregate fresh weights, i.e., twig plus leaf, were recorded.

For determining belowground biomass of A. marina and $S$. alba trees, we first excavated the root crown and then selected two main cable roots from the root crown and two side cable roots from each of the two main cable roots, including their respective pneumatophores, for full excavation. The root selection included one small and one large main and side cable root, respectively, so as to cover as wide ranges of root sizes as
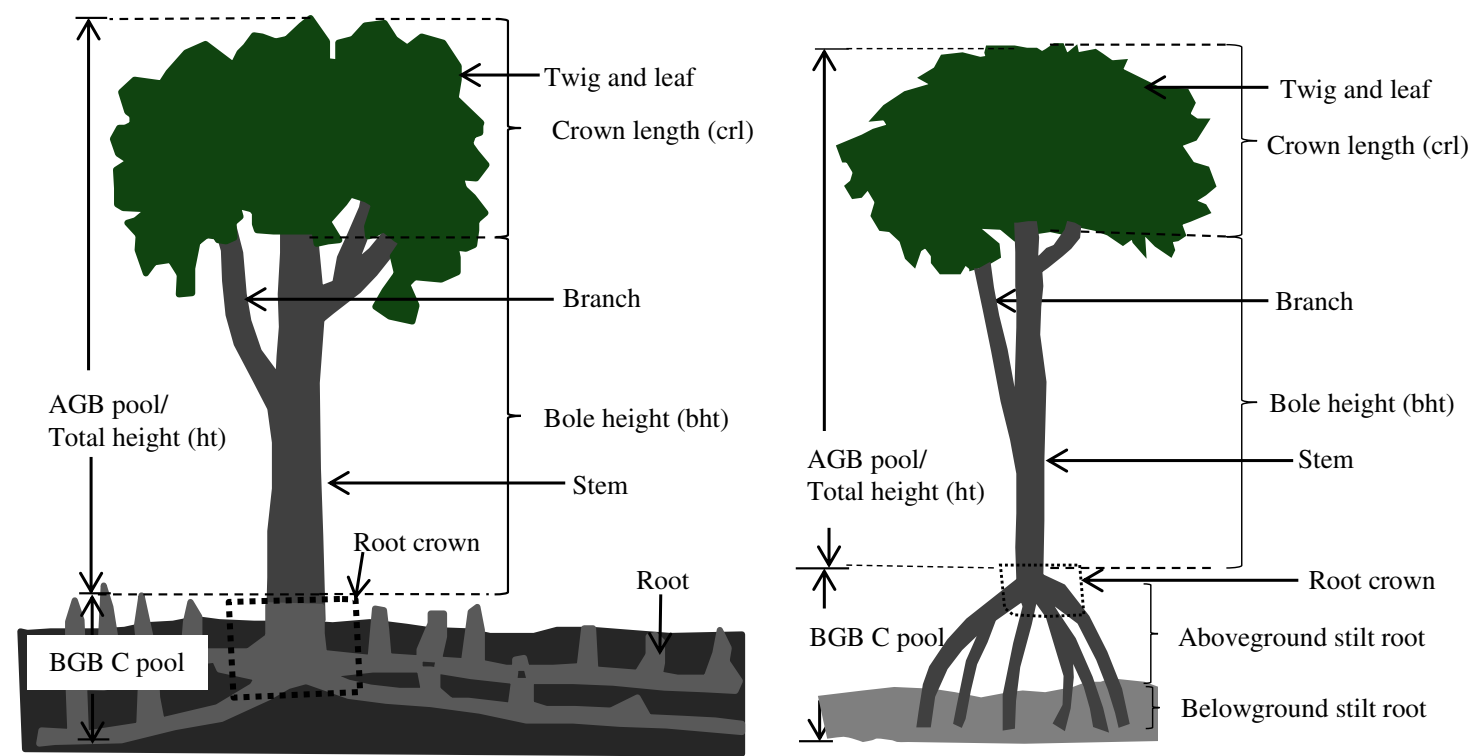

Fig. 1 Schematic sketch of A. marina and S. alba trees (upper panel) and R. mucronata trees (lower panel) showing different tree components and variables. Note: $A G B$ total aboveground biomass, $B G B$ total belowground biomass 
Table 2 Statistical summary of plot variables, sample tree variables, and tree biomass for different tree components

\begin{tabular}{|c|c|c|c|c|c|c|c|c|c|c|c|c|}
\hline \multirow[t]{2}{*}{ Item } & \multicolumn{4}{|c|}{ A. marina } & \multicolumn{4}{|c|}{ S. alba } & \multicolumn{4}{|c|}{ R. mucronata } \\
\hline & $n$ & Mean \pm STD & Min & Max & $n$ & Mean \pm STD & Min & Max & $n$ & Mean \pm STD & Min & Max \\
\hline \multicolumn{13}{|l|}{ Plot variables ${ }^{\mathrm{a}}$} \\
\hline$N\left(\right.$ no. $\left.\mathrm{ha}^{-1}\right)$ & 40 & $622 \pm 402$ & 0 & 1,879 & 39 & $859 \pm 873$ & 0 & 4,076 & 40 & $651 \pm 460$ & 0 & 2,038 \\
\hline$G\left(\mathrm{~m}^{2} \mathrm{ha}^{-1}\right)$ & 40 & $15.3 \pm 10.8$ & 0 & 35.7 & 39 & $13.8 \pm 9.3$ & 0 & 38.4 & 40 & $10.0 \pm 6.2$ & 0 & 27.1 \\
\hline \multicolumn{13}{|l|}{ Sample tree variables } \\
\hline bd (cm) & 40 & $26.9 \pm 18.1$ & 1.7 & 83.6 & 39 & $23.5 \pm 15.0$ & 3.9 & 57.0 & 40 & $21.2 \pm 13.0$ & 1.9 & 42.9 \\
\hline $\mathrm{dbh}(\mathrm{cm})$ & 40 & $22.7 \pm 15.6$ & 1.1 & 70.5 & 39 & $18.2 \pm 13.4$ & 1.1 & 47.5 & 40 & $19.2 \pm 12.3$ & 1.4 & 41.5 \\
\hline ht (m) & 40 & $12.6 \pm 6.3$ & 3.1 & 30.6 & 39 & $11.8 \pm 8.3$ & 3.1 & 28.1 & 40 & $10.2 \pm 6.9$ & 0.8 & 32.2 \\
\hline bht (m) & 40 & $6.2 \pm 4.7$ & 0.8 & 20.0 & 39 & $5.9 \pm 6.2$ & 0.6 & 22.2 & 40 & $4.5 \pm 3.3$ & 0.2 & 12.5 \\
\hline $\operatorname{crd}(\mathrm{m})$ & 40 & $6.0 \pm 4.2$ & 0.7 & 18.8 & 39 & $3.9 \pm 2.7$ & 0.3 & 10.1 & 40 & $4.5 \pm 3.1$ & 0.5 & 12.1 \\
\hline $\operatorname{crl}(\mathrm{m})$ & 40 & $6.5 \pm 2.9$ & 1.2 & 15.1 & 39 & $6.0 \pm 3.1$ & 0.9 & 13.0 & 40 & $5.8 \pm 4.3$ & 0.6 & 21.6 \\
\hline \multicolumn{13}{|c|}{ Sample tree biomass data ${ }^{\mathrm{b}}$} \\
\hline LeafB $\left(\mathrm{kg}\right.$ tree $\left.^{-1}\right)$ & 22 & $37.5 \pm 24.5$ & 6.4 & 88.8 & 12 & $22.8 \pm 19.3$ & 3.2 & 71.9 & 21 & $32.8 \pm 21.8$ & 5.2 & 90.0 \\
\hline TwigB $\left(\mathrm{kg}\right.$ tree $\left.{ }^{-1}\right)$ & 22 & $100.7 \pm 63.7$ & 15.7 & 261.3 & 12 & $55.7 \pm 59.1$ & 5.0 & 246.9 & 21 & $86.8 \pm 60.0$ & 14.3 & 251.3 \\
\hline BranchB $\left(\mathrm{kg}\right.$ tree $\left.{ }^{-1}\right)$ & 22 & $204.0 \pm 246.8$ & 2.2 & $1,160.2$ & 12 & $95.0 \pm 67.5$ & 5.4 & 232.2 & 21 & $191.0 \pm 214.2$ & 3.7 & 814.3 \\
\hline StemB $\left(\mathrm{kg}\right.$ tree $\left.^{-1}\right)$ & 22 & $404.8 \pm 359.3$ & 73.7 & $1,418.5$ & 12 & $402.2 \pm 326.2$ & 22.9 & $1,081.6$ & 21 & $310.8 \pm 166.2$ & 30.6 & 564.3 \\
\hline AGB $\left(\mathrm{kg}\right.$ tree $\left.^{-1}\right)$ & 40 & $447.0 \pm 579.9$ & 0.5 & $2,766.0$ & 39 & $263.0 \pm 343.2$ & 0.6 & $1,202.4$ & 40 & $335.9 \pm 406.5$ & 90.0 & $1,524.0$ \\
\hline BGB $\left(\mathrm{kg}\right.$ tree $\left.{ }^{-1}\right)$ & 10 & $100.5 \pm 93.7$ & 2.1 & 245.9 & 10 & $273.2 \pm 346.7$ & 2.9 & 851.7 & 10 & $232.4 \pm 168.0$ & 1.1 & 569.7 \\
\hline
\end{tabular}

$N$ number of trees, $G$ basal area, $b d$ basal diameter, $d b h$ diameter at breast height, $h t$ total tree height, $b h t$ bole height, $c r d$ crown diameter, $c r l$ crown length, LeafB leaf biomass, TwigB twig biomass, BranchB branch biomass, StemB stem biomass, $A G B$ total aboveground biomass, $B G B$ total belowground biomass

${ }^{\text {a }}$ The statistical summary for plot variables include only trees with $\mathrm{dbh}>5 \mathrm{~cm}$

${ }^{\mathrm{b}}$ Since only tree with $\mathrm{dbh}>15 \mathrm{~cm}$ were partitioned into different aboveground tree components, the sample $(n)$ is less than the expected 40 for each of the three species

possible. Fresh weights as well as root basal diameter of all excavated roots were determined. These measurements were later used to develop side and main cable root regression models, which were applied to predict biomass of roots not excavated (for details on excavation and biomass determination procedures, see Njana et al. 2015). For R. mucronata, fresh weights were determined through harvesting of all aboveground stilt roots followed by complete excavation of all belowground stilt roots. Finally, the total belowground fresh weight was determined by summarizing weights of root crown and above- and belowground stilt roots.

For each tree, three subsamples were extracted from the stem, two from the branches, and two from the twigs. The weight of the subsamples for the aboveground tree components ranged from 0.05 to $4.5 \mathrm{~kg}$. All subsamples were extracted at random locations except for the stem subsamples, which were extracted at 0,40 , and $70 \%$ of the total tree height. The fresh weight of all subsamples was determined immediately after extraction using a digital balance (to the nearest $0.01 \mathrm{~g}$ ). This was followed by labelling and packing for further measurements in laboratory. In total, the numbers of stem, branch, and twig subsamples were 119,50 , and 72 , respectively, for A. marina;
118,39 , and 68 , respectively, for $S$. alba; and 117,46 , and 72 , respectively, for $R$. mucronata. The numbers of root crown and root subsamples were 10 and 19 , respectively, both for A. marina and S. alba. For R. mucronata, 7 subsamples were extracted from root crown, 17 from aboveground stilt roots, and 19 from belowground stilt roots (see Njana et al. 2015).

\subsection{Laboratory procedures and dry weight determination}

In the laboratory, subsamples were oven-dried to constant weight at $105^{\circ} \mathrm{C}$ and their dry weight determined by a digital balance. DF ratio of subsamples (unit less) was determined as oven dry weight $(\mathrm{kg})$ per fresh weight $(\mathrm{kg})$. Exploratory analysis of covariance (ANCOVA) with dbh as a covariate revealed that the DF ratio varied significantly between aboveground tree components and with tree $\mathrm{dbh}(p<0.05)$. In general, DF ratio varied from 0.28 to 0.66 for $A$. marina, 0.22 to 0.69 for $S$. alba, and 0.33 to 0.71 for R. mucronata. Since only 10 trees for each of the three species among the larger trees $(\mathrm{dbh} \geq 15 \mathrm{~cm})$ were partitioned into twig and leaf, we initially computed species-specific twig to leaf ratio based on the 10 observations for each species which was used to partition the 
aggregate twig and leaf component into twig and leaf for trees not partitioned into that level. Then, total tree aboveground biomass was calculated as the product of tree- and componentspecific fresh weight and DF ratio:

$$
\begin{aligned}
\mathrm{AGB}_{h}= & \sum_{i_{s}=1}^{n_{s}}\left(\mathrm{FW}_{h i_{s}} \times \mathrm{DF}_{h_{s}}\right)+\sum_{i_{b}=1}^{n_{b}}\left(\mathrm{FW}_{h i_{b}} \times \mathrm{DF}_{h_{b}}\right) \\
& +\sum_{i_{t}=1}^{n_{t}}\left(\mathrm{FW}_{h i_{t}} \times \mathrm{DF}_{h_{t}}\right)+\sum_{i_{l}=1}^{n_{l}}\left(\mathrm{FW}_{h i_{l}} \times \mathrm{DF}_{h_{l}}\right)
\end{aligned}
$$

where $\mathrm{AGB}_{h}=$ observed total tree aboveground dry weight (kg) of the $h$ th tree, $n=$ total number of billets/twig bundles/ leaf weights for a given aboveground tree component, $s=$ stem, $b=$ branch, $t=$ twig, $l=$ leaf, $i=i$ th subsection, $\mathrm{FW}_{h i_{s}}$, $\mathrm{FW}_{h i_{b}}, \mathrm{FW}_{h i_{t}}$, and $\mathrm{FW}_{h i_{l}}$ are stem, branch, twig, and leaf fresh weights $(\mathrm{kg})$, respectively, and $\mathrm{DF}_{h_{s}}, \mathrm{DF}_{h_{b}}, \mathrm{DF}_{h_{t}}$, and $\mathrm{DF}_{h_{l}}$ are stem, branch, twig, and leaf DF ratios, respectively.

Belowground dry weight determination for A. marina and $S$. alba involved conversion of fresh weight of excavated root components using species-, tree-, and component-specific DF ratios. From excavated sample root dry weight data, regression models for prediction of dry weight of unexcavated roots were developed and dry weights of unexcavated roots were predicted (for details, see Njana et al. 2015). Therefore, total root dry weights comprised excavated and unexcavated (i.e., predicted) root dry weights. Total tree belowground dry weight, i.e., belowground biomass, was derived as the sum of root and root crown dry weight. For $R$. mucronata, tree belowground dry weight was obtained by converting total tree fresh weight to dry weight using tree-specific DF ratios. This was the case because for this species, tree belowground fresh weight was not distinguished into root components. Statistical summary for sample tree dry weights are presented in Table 2.

\subsection{Model specification}

Model specification involves selection of functional form as well as selection of predictor variables. Initially, we tested various functional forms; however, power functional form was the best. Power functions have been widely used to model biomass of mangrove trees (e.g., Tamai et al. 1986; Komiyama et al. 2005; Kairo et al. 2009; Ray et al. 2011; Patil et al. 2014). In this study, two variants of power functions with an additive error term $\left(\varepsilon_{i}\right)$ were considered (model forms Model form 1 and Model form 2):

$B_{i}=\beta_{0} \times\left(\mathrm{dbh}_{i}\right)^{\beta_{1}}+\varepsilon_{i}$

(Modelform1)
$B_{i}=\beta_{0} \times\left(\mathrm{dbh}_{i}\right)^{\beta_{1}}\left(\mathrm{ht}_{i}\right)^{\beta_{2}}+\varepsilon_{i}$

(Modelform2)

where $i$ represent $i$ th observation, and $B_{i}$ represent aboveground biomass, leaf biomass, twig biomass, branch biomass, or stem biomass. Model form Model form 1 represents biomass as a function of $\mathrm{dbh}_{i}$, while model form Model form 2 represents biomass as a function of both $\mathrm{dbh}_{i}$ and $\mathrm{ht}_{i}$, while the betas $(\beta)$ are model parameters.

Diameter at breast height $\left(\mathrm{dbh}_{i}\right)$ is highly correlated with biomass $\left(B_{i}\right)$. However, also ht $t_{i}$ is highly correlated with biomass and could be a useful variable in biomass models to reflect that trees reach their maximum height at an earlier stage than maximum diameter. This means that models depending on dbh only may overpredict biomass of large trees because the biomass increase per unit increase in diameter is reduced when trees approach maximum height. Thus, $\mathrm{ht}_{i}$ represents additional information not reflected by $\mathrm{dbh}_{i}$ (e.g., Chave et al. 2005).

\subsection{Nonlinear mixed effects (NLME) modelling}

\subsubsection{Nonlinear mixed effects models}

Three important assumptions for regression modelling are normality, homoscedasticity (if residual variance increases as a function of dbh), and independency of residuals. Results and conclusions based on regression analysis are only reliable if these assumptions are met (Ritz and Streibig 2008; Zuur et al. 2009). For biological data, however, such assumptions may be difficult to meet. Non-normal residuals, for example, may be due to outliers, while lack of independency of residuals may occur due to the structure of data itself (Zuur et al. 2009). Nonnormal and heteroscedastic residuals may be dealt with by transformation (Ritz and Streibig 2008; Zuur et al. 2009), although this leads into change of the original scale and introduces bias (O'Hara and Kotze 2010; Packard 2009).

NLME modelling is one way to confront challenges encountered in conventional regression approaches since it relaxes regression assumptions and take into account the complex nature of biological data (Pinheiro and Bates 2000; Zuur et al. 2009). Within the mixed effects model framework, parameters may also be allowed to vary by grouping variables(s) (i.e., random variables(s)) (Ritz and Streibig 2008). NLME models may generally be expressed as follows (Lindstrom and Bates 1990; Vonesh and Chinchilli 1997; Pinheiro and Bates 1998):

$y_{i j}=f\left(x_{i j}, \lambda_{j} ; \beta, \alpha_{j}\right)+\varepsilon_{i j}$

where $i=i$ th observation, $j=j$ th random-effect variable, $y_{i j}=$ response variable for observation $i$ and random-effect variable $j, x_{i j}=$ predictor variable for observation $i$ and random-effect 
variable $j, \lambda_{j}=$ random-effect variable for $j, \beta=$ fixed effects parameters, $\alpha_{j}=$ random effects parameters, and $\varepsilon_{i j}=$ error term, which is assumed normally distributed with a mean of zero.

Our data originated from four different sites and comprised three different species, where one tree was destructively sampled from each sample plot spatially distributed along transects. Since our data structure is hierarchical and the biomassdbh relationship is nonlinear (Fig. 2), tree biomass was modelled using the NLME modelling approach in order to preserve the original scale.

Biomass models based on mixed effects modelling frameworks have also previously been developed (e.g., Moore 2010; Li et al. 2011; Xu et al. 2014). The mixed effects modelling provides a statistical capability where fixed- (i.e., populations average) and random effects (i.e., group specific) parameters may be estimated simultaneously (West et al. 2007). Under the mixed effects modelling framework, models including fixed effects parameters may therefore be regarded as common or multi-species models, while those including random effects may be regarded as species-specific models.

\subsubsection{Modelling procedures}

Model development was carried out using the R software version 3.1.2 (R Core Team 2014) using the NLME function in

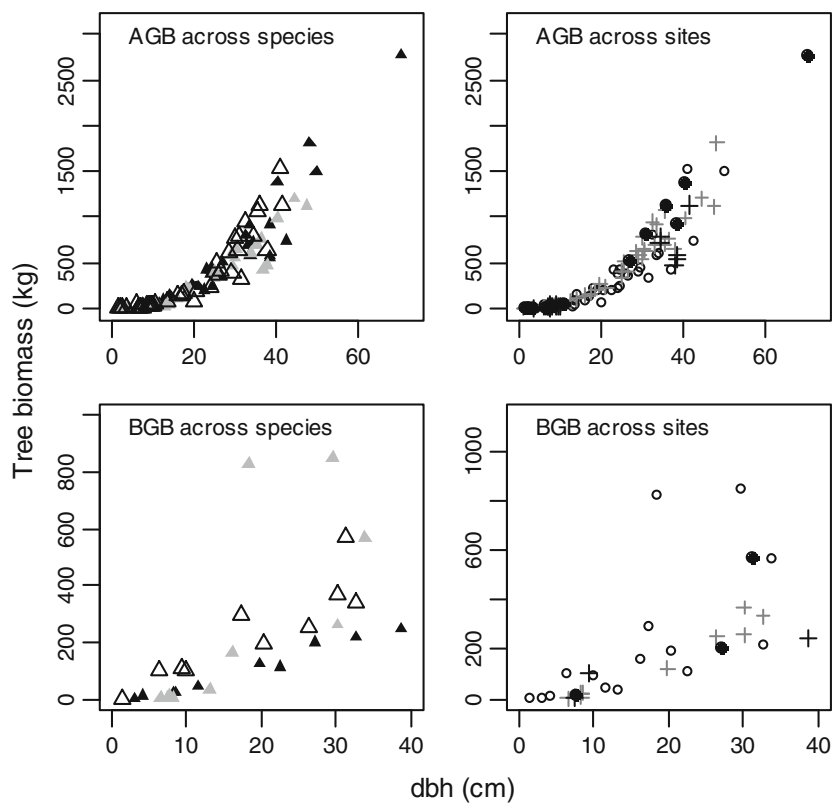

Fig. 2 Above- and belowground tree biomass over dbh across species and sites. Symbols black up-pointing triangle, gray up-pointing triangle, and white up-pointing triangle, respectively, represent A. marina, S. alba, and $R$. mucronata tree species, while black circle, white circle, gray plus sign, and black plus sign, respectively, represent trees from Pangani, Bagamoyo, Rufiji, and Lindi-Mtwara. Note: $A G B=$ total aboveground biomass, $B G B=$ total belowground biomass the NLME package (Pinheiro et al. 2015). In order to specify which parameter to be treated as solely fixed effects and which one as both fixed and random effects, we initially tested each parameter as both fixed and random effects parameters against prospective random effects variables. Prospective random effects variables included species $(j)$ and site $(k)$. The influence of random effects variable(s), individually or in combination on a given parameter, was evaluated using Akaike information criteria (AIC). Accordingly, $\beta_{0}$ (model forms 1 and 2) and $\beta_{2}$ (model form 2) were considered as solely a fixed effects parameter, while $\beta_{1}$ was considered as both fixed and random effects parameters. Model forms 1 and 2 were then respecified to include a random effects parameter $\left(\alpha_{j k}\right)$ (model forms Model form 3 and Model form 4):

$B_{i j k}=\beta_{0} \times\left(\mathrm{dbh}_{i j k}\right)^{\beta_{1}+\alpha_{j k}}+\varepsilon_{i j k}$

(Modelform3)

$B_{i j k}=\beta_{0} \times\left(d b h_{i j k}\right)^{\beta_{1}+\alpha_{j k}}\left(h t_{i j k}\right)^{\beta_{2}}+\varepsilon_{i j k}$

(Modelform4)

Site did not result into significant random parameters $\left(\beta_{1}\right)$, so relevant parameters estimated were not reported. Three sets of biomass models were developed: (i) aboveground biomass models, (ii) belowground biomass models, and (iii) aboveground tree component (leaf, twig, branch, and stem) biomass models. Both model forms 3 and 4 were fitted for total aboveground biomass, while only model form 3 was fitted for belowground biomass and aboveground tree component biomass. Model form 4 was not considered for belowground and aboveground tree components due to limited number of observations (Harrell 2001; Roxburgh et al. 2015).

During explorative data analysis, we observed that residual variances $\left(\sigma^{2}\left(\varepsilon_{i j k}\right)\right)$ were heteroscedastic. Consequently, we assumed heteroscedasticity, and residual variances were modelled as a function of dbh using varPower function in $\mathrm{R}$ (Pinheiro and Bates 2000; Ritz and Streibig 2008; Zuur et al. 2009);

$\sigma^{2}\left(\varepsilon_{i j k}\right)=\sigma^{2} \times\left|\mathrm{dbh}_{i j k}\right|^{2 \phi}$

where $\phi=$ variance function coefficient. We initially also tested other functions in $\mathrm{R}$ (varExp, varIdent, varConstPower, and varComb). However, the varPower function appeared to be the best.

The effects of the variance function were evaluated using AIC. The variance function is implicitly part of the mixed effects model but is not explicitly stated; therefore, the variance functions are not reported in the results (Smith et al. 2014; de Miguel et al. 2014). Since one tree was sampled from each plot and the distance between plots ranged from 150 to $250 \mathrm{~m}$, observations between plots were considered spatially independent; thus, no correlation structure was assumed.

During tests for random and variance function effects, model parameterization was done by using 
maximum likelihood (ML), while we for the final models used restricted ML (REML) (Lindstrom and Bates 1990; Pinheiro and Bates 2000). The models were evaluated using root mean squared error (RMSE (\%)) and mean prediction error (MPE (\%)) (Chai and Draxler 2014; Walther and Moore 2005) as measures of goodness of fit while model selection was done using AIC:

$\operatorname{RMSE}(\%)=\left(\frac{\sqrt{\sum\left(e_{i j k}^{2}\right) / n}}{\mathrm{MB}_{\mathrm{obs}}}\right) \times 100$

$\operatorname{MPE}(\%)=\left(\frac{\sum\left(e_{i j k}\right) / n}{\mathrm{MB}_{\mathrm{obs}}}\right) \times 100$

$\mathrm{AIC}=n \times\left(\ln \left(\frac{\sum\left(e_{i j k}^{2}\right)}{n}\right)\right)+2 \times(p+1)+C$

where $e_{i j k}=$ residuals, i.e., difference between predicted and observed tree biomass $(\mathrm{kg}), n=$ sample size, $\mathrm{MB}_{\text {obs }}=$ mean observed tree biomass $(\mathrm{kg}), \ln =$ natural logarithm, $p=$ number of parameters, and $C=$ constant.

RMSE (\%) represents a measure of accuracy and MPE (\%) a measure of bias. A model with lower RMSE (\%) than the reference model implied the model to be more accurate than the reference model and vice versa. Similarly, MPE (\%) values significantly different from zero implied biased aboveground biomass predictions, i.e., under- or overpredictions; otherwise, they implied unbiased aboveground biomass predictions. The commonly used model selection criterion $R^{2}$ was not considered since its use has been criticized (e.g., Johnson and Omland 2004; Sileshi 2014).

\subsection{Evaluation of predictive accuracy of existing biomass models}

Based on a literature review, relevant existing aboveground biomass models were selected and tested on our data to determine their predictive accuracy. The selected models ensured representation of various regions and included four common and eight species-specific biomass models (Table 3). RMSE (\%), MPE (\%), and AIC served as model evaluation criteria. After computation of these criteria, the existing models were ranked in descending order based on AIC. The existing models were ranked without stratification into model type or predictor variable included since AIC as a model selection criteria is capable of detecting such differences (Burnham et al. 2011).

\section{Results}

\subsection{Distribution of biomass into different tree parts}

The three mangrove species considered in this study stored between $49 \%$ (R. mucronata) and $72 \%$ (S. alba) of aboveground biomass in the stem, while the rest in descending order was stored in branch, twig, and leaf (Fig. 3). On average, about $41 \%$ of the total tree biomass is stored in the root system (Fig. 4). Figures 3 and 4 show that S. alba had relatively higher stem biomass and higher root biomass compared to the other species. The root-to-shoot ratios for A. marina, $S$. alba, and R. mucronata were $0.38,1.29$, and 0.62 , respectively, with an overall mean of 0.70 . Generally, the root-toshoot ratio depicted a decreasing trend from lower to higher dbh classes.

\subsection{Biomass models}

All parameter estimates for the above- and belowground biomass models were statistically significant (Table 4). For the aboveground biomass fixed effects models (FE1, FE2), inclusion of ht as a predictor variable was important since RMSE decreased from 42.6 to $38.4 \%$, which is equivalent to a decline of about $10 \%$. Based on AIC as model selection criterion, the fixed effects model FE2 is better than model FE1. For the aboveground biomass random effects models, inclusion of ht resulted in lower RMSE (\%) and MPE (\%) values for A. marina (models RE1 and RE4) and S. alba (models RE2 and RE5), while mixed results were observed for R. mucronata (models RE3 and RE6).

The evaluation of the aboveground biomass models (Table 5) showed that inclusion of ht as predictor variable (model form 4) generally improved predictive accuracy, i.e., provided lower MPE values. The results also showed that the random effects models with ht as a predictor variable were more accurate than the fixed effects models.

For the belowground biomass models (Table 4), the goodness of fit statistics, i.e., RMSE (\%) and MPE (\%), improved when using random effects for A. marina (model RE7) and $R$. mucronata (model RE9) compared to the fixed effects model (model FE3), while the opposite was observed for S. alba (model RE8).

The $\beta_{0}$ parameter estimates of the aboveground tree components biomass models were statistically non-significant $(p>0.05)$ except for the stem biomass model (Table 6). All other parameter estimates were statistically significant $(p<0.05)$. MPEs were slightly lower than $10 \%$ for the leaf, twig, and branch biomass models, while MPE was slightly higher than $10 \%$ for the stem model. The stem biomass model had lower RMSE (\%) values compared to all the other component models. 
Table 3 Existing aboveground biomass mangrove models selected for evaluation of prediction accuracy

\begin{tabular}{|c|c|c|c|c|c|c|c|}
\hline Model type & Model & $n$ & $R^{2}$ & RMSE & $\mathrm{dbh}(\mathrm{cm})$ & Location & Author \\
\hline Common & $\mathrm{AGB}=3.254 \times \exp (0.065 \times \mathrm{dbh})$ & 31 & 0.89 & 4.244 & $0.5-42$ & $\begin{array}{l}\text { Sofala bay, } \\
\text { Mozambique }\end{array}$ & Sitoe et al. (2014) \\
\hline Common & $\mathrm{AGB}=1.3799 \times \mathrm{dbh}^{0.955} \times \mathrm{ht}^{0.687}$ & 100 & 0.98 & - & - & India & Ray et al. (2011) \\
\hline Common & $\mathrm{AGB}=0.0509 \times \rho\left(\mathrm{dbh}^{2} \times \mathrm{ht}\right)$ & 84 & 0.96 & - & $\mathrm{dbh}_{\max }=42$ & $\begin{array}{l}\text { French Guiana and } \\
\text { Guadeloupe }\end{array}$ & Chave et al. (2005) \\
\hline Common & $\mathrm{AGB}=0.251 \times \rho \times \mathrm{dbh}^{2.46}$ & 104 & 0.98 & 0.085 & $5.0-48.9$ & Thailand and Indonesia & Komiyama et al. (2005) \\
\hline \multicolumn{8}{|l|}{ A. marina } \\
\hline $\begin{array}{l}\text { Species- } \\
\text { specific }\end{array}$ & $\mathrm{AGB}=0.3404 \times \mathrm{dbh}^{2.0273}$ & 110 & 0.94 & - & - & Mumbai, India & Patil et al. (2014) \\
\hline $\begin{array}{l}\text { Species- } \\
\text { specific }\end{array}$ & $\mathrm{AGB}=\exp (0.2540+0.9140 \times \log (\mathrm{dbh}))$ & 10 & 0.31 & 1.340 & $8^{\mathrm{a}}$ & Gazi Bay, Kenya & Kairo et al. (2009) \\
\hline $\begin{array}{l}\text { Species- } \\
\text { specific }\end{array}$ & $\mathrm{AGB}=0.1036 \times \mathrm{dbh}^{2}+0.5402 \times \mathrm{dbh}+(-1.5674)$ & - & 0.94 & - & $2.1-12.1$ & Taiwan & Kuei (2008) \\
\hline $\begin{array}{l}\text { Species- } \\
\text { specific }\end{array}$ & $\mathrm{AGB}=0.308 \times \mathrm{dbh}^{2.11}$ & 22 & 0.97 & 0.023 & $\mathrm{dbh}_{\max }=35$ & Darwin, Australia & $\begin{array}{l}\text { Comley and McGuinness } \\
\text { (2005) }\end{array}$ \\
\hline \multicolumn{8}{|l|}{ S. alba } \\
\hline $\begin{array}{l}\text { Species- } \\
\text { specific }\end{array}$ & $\mathrm{AGB}=0.0825 \times \rho \times\left(\mathrm{dbh}^{2} \times \mathrm{ht}\right)^{0.89966}$ & 345 & 0.95 & - & $\mathrm{dbh}_{\max }=323$ & Palau & $\begin{array}{l}\text { Kauffman and Donato } \\
\text { (2012) }\end{array}$ \\
\hline $\begin{array}{l}\text { Species- } \\
\text { specific } \\
\text { R. mucronata }\end{array}$ & $\mathrm{AGB}=\exp (0.6715+0.1473 \times \log (\mathrm{dbh}))$ & 10 & 0.01 & 0.580 & $10^{\mathrm{a}}$ & Gazi Bay, Kenya & Kairo et al. (2009) \\
\hline $\begin{array}{l}\text { Species- } \\
\text { specific }\end{array}$ & $\mathrm{AGB}=0.0311 \times \rho \times\left(\mathrm{dbh}^{2} \times \mathrm{ht}\right)^{1.00741}$ & 73 & 0.95 & - & $\mathrm{dbh}_{\max }=39.5$ & Palau & $\begin{array}{l}\text { Kauffman and Donato } \\
\text { (2012) }\end{array}$ \\
\hline $\begin{array}{l}\text { Species- } \\
\text { specific }\end{array}$ & $\mathrm{AGB}=\exp (-0.1811+0.6590 \times \log (\mathrm{dbh}))$ & 5 & 0.83 & 1.050 & $5^{\mathrm{a}}$ & Gazi Bay, Kenya & Kairo et al. (2009) \\
\hline
\end{tabular}

Units of measurement: total aboveground biomass, kilogram; diameter at breast height, centimeter; total height (ht), meter; basic density, gram per cubic centimeter

$A G B$ total aboveground biomass, $d b h$ diameter at breast height, $h t$ total height, $\rho$ basic density, $n$ sample sizes

a The figure refer to the fixed age of planted mangrove trees which is surrogate to dbh

Using paired $t$ test, comparisons of observed total tree aboveground biomass with total tree aboveground biomass predicted the tree components common/fixed effects models showed that the prediction errors were

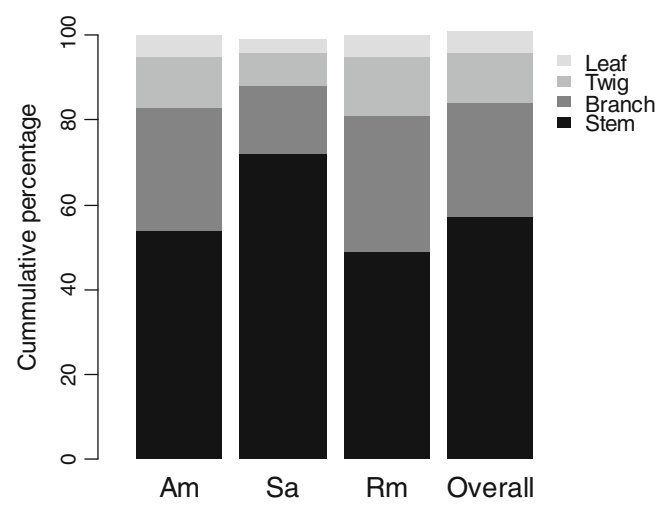

Fig. 3 Distribution of biomass between aboveground tree components. $A m=A$. marina $(n=23), S a=S$. alba $(n=17)$, and $R m=R$. mucronata $(n=21)$ non-significant for A. marina $(n=23, \mathrm{MPE}=-6.5 \%$, $p>0.05)$ and $S$. alba $(n=17, \mathrm{MPE}=3.9 \%, p>0.05)$, while they were significant for $R$. mucronata $(n=21$, MPE $=16.0 \%, p<0.05)$.

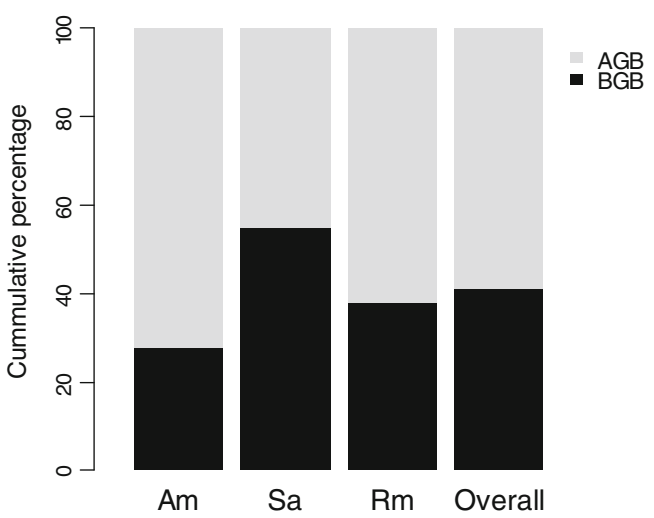

Fig. 4 Distribution between above- and belowground biomass. Am = A. marina $(n=10), S a=S$. alba $(n=10)$, and $R m=R$. mucronata $(n=$ 10). Note: $A G B=$ total aboveground biomass, $B G B=$ total belowground biomass 
Table 4 Above- and belowground biomass models

\begin{tabular}{|c|c|c|c|c|c|c|c|c|c|c|c|c|c|c|}
\hline \multirow{2}{*}{$\begin{array}{l}\mathrm{AGB} / \\
\mathrm{BGB}\end{array}$} & \multirow{2}{*}{$\begin{array}{l}\text { Model } \\
\text { form }\end{array}$} & \multirow{2}{*}{$\begin{array}{l}\text { Model } \\
\text { category }\end{array}$} & \multirow[t]{2}{*}{ Model type } & \multirow[t]{2}{*}{$n$} & \multicolumn{6}{|c|}{ Parameter estimates } & \multirow{2}{*}{$\begin{array}{l}\text { RMSE } \\
(\%)\end{array}$} & \multirow{2}{*}{$\begin{array}{l}\text { MPE } \\
(\%)\end{array}$} & \multirow[t]{2}{*}{ AIC } & \multirow[t]{2}{*}{ Model } \\
\hline & & & & & $\beta_{0}$ & $\mathrm{SE}_{\beta 0}$ & $\beta_{1}$ & $\mathrm{SE}_{\beta 1}$ & $\beta_{2}$ & $\mathrm{SE}_{\beta 2}$ & & & & \\
\hline \multirow[t]{6}{*}{ AGB } & \multirow[t]{6}{*}{3} & $\begin{array}{l}\text { Fixed } \\
\text { effects }\end{array}$ & Common & \multirow[t]{2}{*}{119} & $0.25128^{\mathrm{c}}$ & 0.04146 & $2.24034^{\mathrm{c}}$ & 0.05087 & - & - & 42.6 & -0.6 & $1,203.9$ & FE1 \\
\hline & & \multirow[t]{5}{*}{$\begin{array}{r}\text { Random } \\
\text { effects }\end{array}$} & $\begin{array}{l}\text { Species- } \\
\text { specific }\end{array}$ & & $\beta_{0}$ & $\mathrm{SE}_{\beta 0}$ & $\beta_{1+} \alpha_{1}$ & $\mathrm{SE}_{\beta 1}$ & $\beta_{2}$ & $\mathrm{SE}_{\beta 2}$ & & & & \\
\hline & & & A. marina & 40 & $0.25128^{\mathrm{c}}$ & 0.04146 & $2.24351^{\mathrm{c}}$ & 0.05087 & - & - & 41.3 & 2.8 & 421.5 & RE1 \\
\hline & & & S. alba & 39 & $0.25128^{\mathrm{c}}$ & 0.04146 & $2.21727^{\mathrm{c}}$ & 0.05087 & - & - & 34.2 & 2.8 & 355.0 & RE2 \\
\hline & & & & 40 & $0.25128^{\mathrm{c}}$ & 0.04146 & $2.26026^{\mathrm{c}}$ & 0.05087 & - & - & 40.5 & -6.6 & 397.0 & RE3 \\
\hline & & & $\begin{array}{l}\text { R. mucr- } \\
\text { onata }\end{array}$ & & & & & & & & & & & \\
\hline \multirow[t]{7}{*}{ AGB } & \multirow[t]{7}{*}{4} & \multirow{2}{*}{$\begin{array}{l}\text { Fixed } \\
\text { effects }\end{array}$} & Common & \multirow[t]{3}{*}{119} & $\beta_{0}$ & $\mathrm{SE}_{\beta 0}$ & $\beta_{1}$ & $\mathrm{SE}_{\beta 1}$ & $\beta_{2}$ & $\mathrm{SE}_{\beta 2}$ & & & & \\
\hline & & & & & $0.19633^{\mathrm{c}}$ & 0.03095 & $2.07919^{c}$ & 0.05652 & $0.29654^{\mathrm{c}}$ & 0.05552 & 38.4 & -1.0 & $1,180.5$ & FE2 \\
\hline & & \multirow[t]{5}{*}{$\begin{array}{r}\text { Random } \\
\text { effects }\end{array}$} & $\begin{array}{l}\text { Species- } \\
\text { specific }\end{array}$ & & $\beta_{0}$ & $\mathrm{SE}_{\beta 0}$ & $\beta_{1+} \alpha_{1}$ & $\mathrm{SE}_{\beta 1}$ & $\beta_{2}$ & & & & & \\
\hline & & & A. marina & 40 & $0.19633^{\mathrm{c}}$ & 0.03095 & $2.08791^{\mathrm{c}}$ & 0.05652 & $0.29654^{\mathrm{c}}$ & 0.05552 & 31.4 & 1.6 & 401.6 & RE4 \\
\hline & & & S. alba & 39 & $0.19633^{\mathrm{c}}$ & 0.03095 & $2.04113^{\mathrm{c}}$ & 0.05652 & $0.29654^{\mathrm{c}}$ & 0.05552 & 23.1 & 2.0 & 326.6 & RE5 \\
\hline & & & & 40 & $0.19633^{\mathrm{c}}$ & 0.03095 & $2.10853^{\mathrm{c}}$ & 0.05652 & $0.29654^{\mathrm{c}}$ & 0.05552 & 42.5 & -4.6 & 403.0 & RE6 \\
\hline & & & $\begin{array}{l}\text { R. mucr- } \\
\text { onata }\end{array}$ & & & & & & & & & & & \\
\hline \multirow[t]{7}{*}{ BGB } & \multirow[t]{7}{*}{3} & \multirow{2}{*}{$\begin{array}{l}\text { Fixed } \\
\text { effects }\end{array}$} & Common & \multirow[t]{2}{*}{30} & $\beta_{0}$ & $\mathrm{SE}_{\beta 0}$ & $\beta_{1}$ & $\mathrm{SE}_{\beta 1}$ & $\beta_{2}$ & $\mathrm{SE}_{\beta 2}$ & & & & \\
\hline & & & & & $1.42040^{\mathrm{b}}$ & 0.50833 & $1.59666^{\mathrm{c}}$ & 0.14425 & - & - & 89.6 & -18.2 & 315.9 & FE3 \\
\hline & & $\begin{array}{l}\text { Random } \\
\text { effects }\end{array}$ & $\begin{array}{l}\text { Species- } \\
\text { specific }\end{array}$ & & $\beta_{0}$ & $\mathrm{SE}_{\beta 0}$ & $\beta_{1+} \alpha_{1}$ & $\mathrm{SE}_{\beta 1}$ & $\beta_{2}$ & $\mathrm{SE}_{\beta 2}$ & & & & \\
\hline & & & A. marina & 10 & $1.42040^{\mathrm{b}}$ & 0.50833 & $1.44260^{\mathrm{c}}$ & 0.14425 & - & - & 16.8 & 1.5 & 60.6 & RE7 \\
\hline & & & S. alba & 10 & $1.42040^{\mathrm{b}}$ & 0.50833 & $1.65760^{\mathrm{c}}$ & 0.14425 & - & - & 95.1 & -32.1 & 115.2 & RE8 \\
\hline & & & & 10 & $1.42040^{\mathrm{b}}$ & 0.50833 & $1.68979^{\mathrm{c}}$ & 0.14425 & - & - & 38.7 & 1.6 & 94.0 & RE9 \\
\hline & & & $\begin{array}{l}\text { R. mucr- } \\
\text { onata }\end{array}$ & & & & & & & & & & & \\
\hline
\end{tabular}

$S E$ standard error of a parameter estimate, $N S$ not significant at $5 \%, A G B$ total aboveground biomass $(\mathrm{kg}), B G B$ total belowground biomass (kg), $n$ sample sizes

${ }^{\text {a }}$ Significant at $5 \%$

${ }^{\mathrm{b}}$ Significant at $1 \%$

${ }^{\mathrm{c}}$ Significant at $0.1 \%$

\subsection{Evaluation of predictive accuracy of existing aboveground biomass models}

The predictive accuracy of the existing aboveground biomass models was evaluated by testing them on our data (Table 7). Judged by AIC, the common model developed by Chave et al. (2005) was the best for prediction of aboveground biomass for A. marina and $S$. alba, while the common model developed by and Komiyama et al. (2005) was the best for $R$. mucronata (Table 7). Except for the model developed by Chave et al. (2005) applied for S. alba and R. mucronata, MPE (\%) values for all tested models were significantly $(p<0.05)$ different from zero.

When ranking the models developed in this study based on AIC, the common (fixed effects) model was the best in prediction of aboveground biomass for
A. marina while the species-specific (random effects) models were the best for the other two species (Table 7). The MPE (\%) values of all the speciesspecific (random effects) models were low and non-significant. For the common (fixed effects) models, the MPE (\%) values were low for A. marina and relatively high for S. alba and R. mucronata. However, only the MPE (\%) value of common model for S. alba was significantly different from zero.

The models developed by Kairo et al. (2009) and Sitoe et al. (2014), both from eastern Africa, were the poorest performing models as demonstrated by very high RMSE (\%) and MPE (\%) values (Table 7). These models were also characterized by remarkable disagreement between observed and predicted biomass values (Fig. 5). 
Table 5 Mean prediction errors (MPE (\%)) of the aboveground biomass models over site, dbh class, and ht class

\begin{tabular}{|c|c|c|c|c|c|}
\hline \multirow[t]{3}{*}{ Parameter } & \multirow[t]{3}{*}{$n$} & \multicolumn{4}{|l|}{ MPE (\%) } \\
\hline & & \multicolumn{2}{|l|}{ Model form 3} & \multicolumn{2}{|l|}{ Model form 4} \\
\hline & & Fixed effects model & Random effects model & Fixed effects model & Random effects model \\
\hline \multicolumn{6}{|l|}{ Site } \\
\hline Pangani & 15 & -4.4 & -2.2 & -9.1 & 4.6 \\
\hline Bagamoyo & 45 & 7.3 & 8.2 & -2.9 & -1.3 \\
\hline Rufiji & 45 & -9.5 & -10.7 & 2.2 & -0.0 \\
\hline Lindi-Mtwara & 15 & 20.8 & 22.9 & 5.0 & 8.8 \\
\hline \multicolumn{6}{|l|}{ dbh class $(\mathrm{cm})$} \\
\hline $1.0-10.0$ & 45 & 12.8 & 12.6 & 10.3 & 9.8 \\
\hline $10.1-20.0$ & 20 & -3.2 & -3.6 & -2.7 & -2.9 \\
\hline $20.1-30.0$ & 20 & -4.7 & -3.4 & -5.5 & -3.8 \\
\hline $30.1-40.0$ & 24 & -1.4 & -0.7 & -1.2 & 0.1 \\
\hline 40.0 & 10 & 2.0 & 1.8 & 1.1 & 0.8 \\
\hline \multicolumn{6}{|l|}{ ht class (m) } \\
\hline $1.0-5.0$ & 24 & 10.2 & 11.7 & -10.8 & -9.5 \\
\hline $5.1-10.0$ & 36 & 25.2 & 24.7 & 8.4 & 7.9 \\
\hline $10.1-15.0$ & 29 & 4.7 & 6.7 & -3.6 & -0.2 \\
\hline $15.1-20.0$ & 14 & -15.1 & -12.0 & -14.8 & -9.5 \\
\hline$>20.0$ & 16 & -3.2 & -6.8 & 11.8 & 5.6 \\
\hline
\end{tabular}

$n$ sample sizes

\section{Discussion}

The distributions of the aboveground biomass components were quite similar for A. marina and R. mucronata, while for $S$. alba, the proportion of stem biomass was higher than for the two other species (Fig. 3). Although on average $41 \%$ of tree biomass was stored belowground, S. alba stored the largest proportion belowground (Fig. 4). The main reason for the relatively large proportion of belowground biomass for $S$. alba, as compared to $A$. marina, is probably due to the large pneumatophores of this species (Njana et al. 2015). This is also in line with the high root-to-shoot ratio for this species. Apparently, S. alba has more belowground biomass than aboveground biomass (1.29 root-to-shoot ratio). Variation of distribution of biomass into different tree components between species and a declining trend in root-to-shoot ratios over dbh classes demonstrate the strategies of trees as they grow; at early stages, more biomass is distributed in the belowground for anchorage and stabilization in the soft substrate, while at later stages, more of the biomass is distributed to the aboveground part in support of physiological processes for growth. The distribution of biomass observed in this study is not unique for mangrove alone as

Table 6 Aboveground tree component biomass models

\begin{tabular}{|c|c|c|c|c|c|c|c|c|c|c|c|c|}
\hline \multirow[t]{2}{*}{ Component } & \multirow[t]{2}{*}{ Model form } & \multirow[t]{2}{*}{ Model category } & \multirow[t]{2}{*}{ Model type } & \multirow[t]{2}{*}{$n$} & \multicolumn{4}{|c|}{ Parameter estimates } & \multirow[t]{2}{*}{ RMSE (\%) } & \multirow[t]{2}{*}{ MPE (\%) } & \multirow[t]{2}{*}{ AIC } & \multirow[t]{2}{*}{ Model } \\
\hline & & & & & $\beta_{0}$ & $\mathrm{SE}_{\beta 0}$ & $\beta_{1}$ & $\mathrm{SE}_{\beta 1}$ & & & & \\
\hline Leaf & 3 & Fixed effects & Common & 55 & $0.91766^{\mathrm{NS}}$ & 0.64173 & $1.04996^{\mathrm{c}}$ & 0.20549 & 62.1 & 8.2 & 367.8 & CFE1 \\
\hline Twig & 3 & Fixed effects & Common & 55 & $0.83391^{\mathrm{NS}}$ & 0.65931 & $1.35324^{\mathrm{c}}$ & 0.23032 & 68.2 & 8.7 & 496.9 & CFE2 \\
\hline Branch & 3 & Fixed effects & Common & 55 & $0.05140^{\mathrm{NS}}$ & 0.05060 & $2.28062^{\mathrm{c}}$ & 0.27769 & 78.0 & -8.4 & 598.5 & CFE3 \\
\hline Stem & 3 & Fixed effects & Common & 55 & $0.24370^{\mathrm{a}}$ & 0.11111 & $2.06187^{\mathrm{c}}$ & 0.13711 & 49.9 & -11.4 & 641.2 & CFE4 \\
\hline
\end{tabular}

$S E$ standard error of a parameter estimate, $N S$ not significant at $5 \%, n$ sample sizes

${ }^{\text {a }}$ Significant at $5 \%$

${ }^{\mathrm{b}}$ Significant at $1 \%$

${ }^{\mathrm{c}}$ Significant at $0.1 \%$ 
Table 7 Predictive accuracy of existing aboveground biomass models and models developed in this study

\begin{tabular}{|c|c|c|c|c|c|c|c|}
\hline Species & Source & Model type & Predictor variables & $n$ & RMSE (\%) & $\operatorname{MPE}^{\mathrm{a}}(\%)$ & $\mathrm{AIC}$ \\
\hline \multirow[t]{12}{*}{ A. marina } & Chave et al. (2005) & Common & $\mathrm{dbh}, \mathrm{ht}, \rho$ & 40 & 41.5 & $-19.0^{\mathrm{b}}$ & 425.8 \\
\hline & Comley and McGuinness (2005) & Species-specific & $\mathrm{dbh}$ & 40 & 45.7 & $-22.7^{\mathrm{c}}$ & 429.6 \\
\hline & Patil et al. (2014) & Species-specific & $\mathrm{dbh}$ & 40 & 65.6 & $-36.8^{\mathrm{c}}$ & 458.4 \\
\hline & Komiyama et al. (2005) & Common & $\mathrm{dbh}, \rho$ & 40 & 104.8 & $36.9^{\mathrm{a}}$ & 498.0 \\
\hline & Ray et al. (2011) & Common & dbh, ht & 40 & 118.0 & $-62.7^{\mathrm{c}}$ & 507.4 \\
\hline & Kuei (2008)) & Species-specific & $\mathrm{dbh}$ & 40 & 132.4 & $-80.2^{\mathrm{c}}$ & 514.7 \\
\hline & Sitoe et al. (2014) & Common & $\mathrm{dbh}$ & 40 & 151.2 & $-94.0^{\mathrm{c}}$ & 525.3 \\
\hline & Kairo et al. (2009) & Species-specific & $\mathrm{dbh}$ & 40 & 157.3 & $-95.1^{\mathrm{c}}$ & 528.4 \\
\hline & This study & Common & $\mathrm{dbh}, \mathrm{ht}$ & 40 & 29.3 & $-1.6^{\mathrm{NS}}$ & 395.9 \\
\hline & This study & Species-specific & dbh, ht & 40 & 31.4 & $1.6^{\mathrm{NS}}$ & 401.6 \\
\hline & This study & Common & $\mathrm{dbh}$ & 40 & 40.6 & $1.6^{\mathrm{NS}}$ & 419.5 \\
\hline & This study & Species-specific & $\mathrm{dbh}$ & 40 & 41.3 & $2.8^{\mathrm{NS}}$ & 421.5 \\
\hline \multirow[t]{10}{*}{ S. alba } & Chave et al. (2005) & Common & dbh, ht, $\rho$ & 39 & 47.1 & $1.6^{\mathrm{NS}}$ & 383.9 \\
\hline & Kauffman and Donato (2012) & Species-specific & $\mathrm{dbh}, \mathrm{ht}, \rho$ & 39 & 62.8 & $-40.4^{\mathrm{c}}$ & 406.3 \\
\hline & Komiyama et al. (2005) & Common & $\mathrm{dbh}, \rho$ & 39 & 70.8 & $29.7^{\mathrm{b}}$ & 413.7 \\
\hline & Ray et al. (2011) & Common & dbh, ht & 39 & 87.6 & $-45.9^{\mathrm{c}}$ & 430.3 \\
\hline & Sitoe et al. (2014) & Common & $\mathrm{dbh}$ & 39 & 154.8 & $-94.0^{\mathrm{c}}$ & 472.7 \\
\hline & Kairo et al. (2009) & Specific & $\mathrm{dbh}$ & 39 & 162.3 & $-98.9^{\mathrm{c}}$ & 476.4 \\
\hline & This study & Species-specific & dbh, ht & 39 & 23.1 & $2.0^{\mathrm{NS}}$ & 326.4 \\
\hline & This study & Species-specific & $\mathrm{dbh}$ & 39 & 34.2 & $2.8^{\mathrm{NS}}$ & 355.0 \\
\hline & This study & Common & dbh, ht & 39 & 39.8 & $16.5^{b}$ & 368.1 \\
\hline & This study & Common & $\mathrm{dbh}$ & 39 & 40.5 & $11.4^{\mathrm{NS}}$ & 368.8 \\
\hline \multirow[t]{10}{*}{ R.mucronata } & Komiyama et al. (2005) & Common & $\mathrm{dbh}, \rho$ & 40 & 56.9 & $29.4^{\mathrm{c}}$ & 426.2 \\
\hline & Chave et al. (2005) & Common & dbh, ht, $\rho$ & 40 & 72.3 & $-17.8^{\mathrm{NS}}$ & 447.4 \\
\hline & Kauffman and Donato (2012) & Species-specific & dbh, ht, $\rho$ & 40 & 87.7 & $-46.0^{\mathrm{c}}$ & 462.9 \\
\hline & Ray et al. (2011) & Common & dbh, ht & 40 & 109.9 & $-60.7^{\mathrm{c}}$ & 478.9 \\
\hline & Sitoe et al. (2014) & Common & $\mathrm{dbh}$ & 40 & 150.2 & $-94.4^{\mathrm{c}}$ & 501.9 \\
\hline & Kairo et al. (2009) & Species-specific & $\mathrm{dbh}$ & 40 & 154.2 & $-98.4^{\mathrm{c}}$ & 504.0 \\
\hline & This study & Species-specific & $\mathrm{dbh}$ & 40 & 40.5 & $-6.6^{\mathrm{NS}}$ & 397.0 \\
\hline & This study & Species-specific & dbh, ht & 40 & 42.5 & $-4.6^{\mathrm{NS}}$ & 403.0 \\
\hline & This study & Common & $\mathrm{dbh}$ & 40 & 44.7 & $-12.7^{\mathrm{NS}}$ & 405.0 \\
\hline & This study & Common & $\mathrm{dbh}, \mathrm{h}$ & 40 & 47.6 & $13.7^{\mathrm{NS}}$ & 412.0 \\
\hline
\end{tabular}

Existing models and models from this study are ranked separately and according to AIC in descending order

$N S$ not significant at $5 \%, n$ sample sizes

${ }^{\text {a }}$ Two-tailed t-tests

${ }^{\mathrm{b}}$ Significant at $5 \%$

${ }^{\mathrm{b}}$ Significant at $1 \%$

${ }^{\mathrm{c}}$ Significant at $0.1 \%$

similar observations have also been reported for miombo woodlands (e.g., Mugasha et al. 2013).

Our study presents above- and belowground biomass models based on data from three dominant mangrove species in Tanzania, i.e., A. marina, S. alba, and R. mucronata. No similar models have previously been developed in the country, and only a few models have been developed in Africa or are based on data from Africa. The existing biomass models from
Africa (Kairo et al. 2009; Sitoe et al. 2014) are based on limited sample sizes and data from only one site. Our biomass models however are based on data from a range of sites along the coastline of Tanzania, covering a size range beyond data used in developing the existing aboveground biomass models both in Africa (e.g., Kairo et al. 2009; Sitoe et al. 2014) and beyond (e.g., Comley and McGuinness 2005; Chave et al. 2005; Komiyama et al. 2005; Kuei 2008; Patil et al. 2014). 


\section{A. marina}
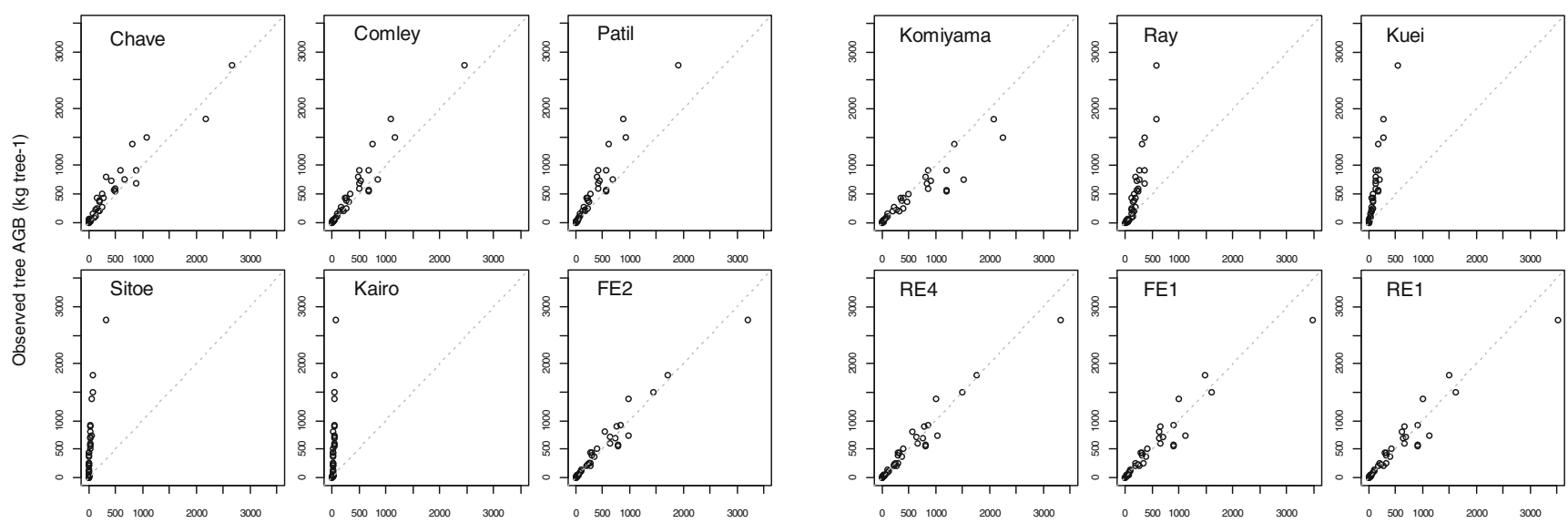

\section{S. alba}
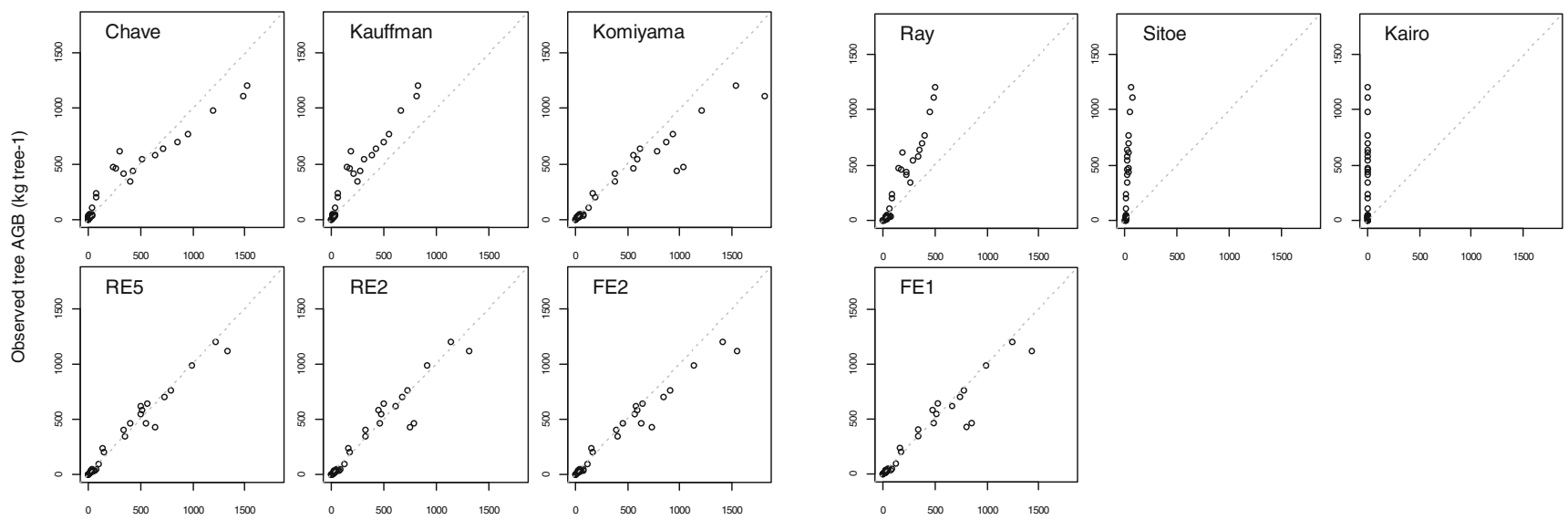

\section{R. mucronata}
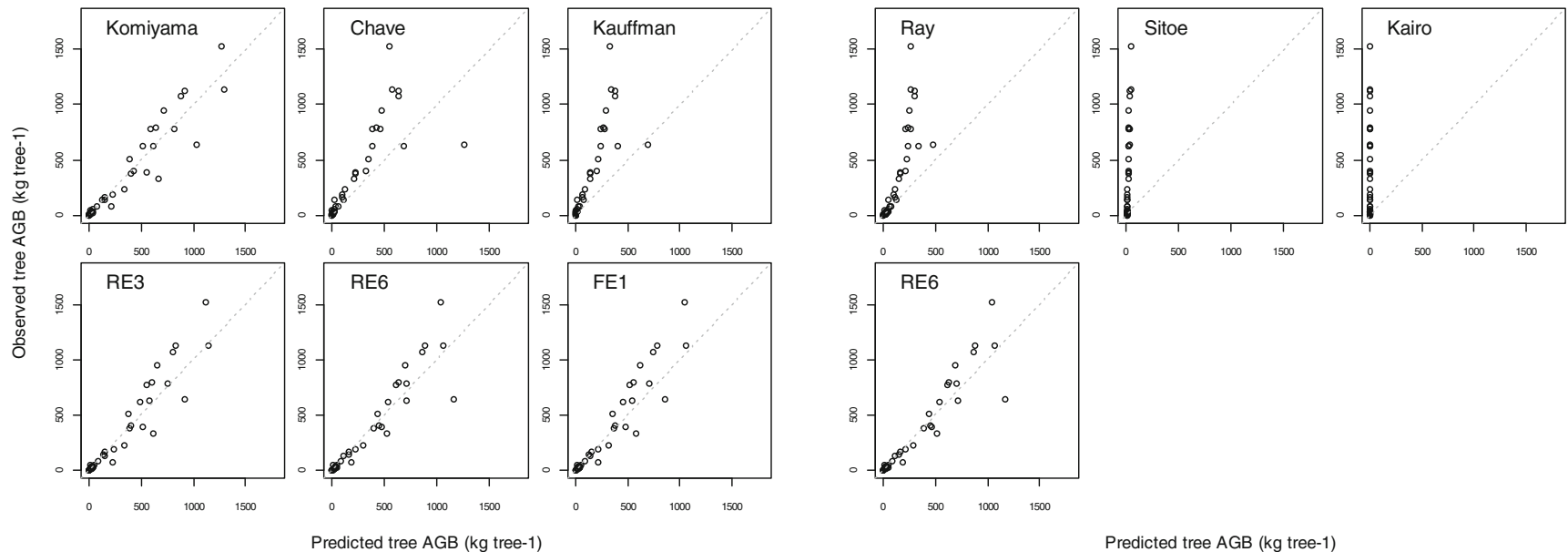

Fig. 5 Observed and predicted aboveground biomass for existing models and for models from this study. Note: Dashed gray lines represent 1:1 relationship between observed and predicted values. $A G B=$ total aboveground biomass, $B G B=$ total belowground biomass

Accordingly, our belowground biomass models are based on data size range beyond those reported in existing studies (e.g., Comley and McGuinness 2005; Komiyama et al. 2005; Kairo et al. 2009). In addition, our belowground biomass models are based on data generated using comprehensive procedures for quantifying tree belowground biomass involving root sampling (A. marina and S. alba) and complete root excavation (R. mucronata) (Njana et al. 2015). 
Our models are based on a nonlinear mixed-modelling approach. Ordinary nonlinear regression is commonly used to develop biomass models. Such models, however, may violate regression assumptions of homoscedasticity and independence of residuals, which are difficult to meet for biological data. Sampling for biomass model development often results in hierarchical data. Chave et al. (2005) and Komiyama et al. (2005) for example developed common biomass models using data originating from more than one site, such data form hierarchical data structure stratified by site and species. Observations originating from the same species and or site are likely to be more correlated hence lack of independence. A model based on non-independent observations is characterized by autocorrelated errors and therefore violate key assumptions of independence in regression (Ritz and Streibig 2008). Ignoring lack of independence tends to give imprecise parameter estimates (ibid.). The mixed effects modelling comprising both fixed and random effects that we applied in this study is a useful statistical tool in modelling hierarchical data (Ritz and Streibig 2008; Zuur et al. 2009).

Our study showed that the aboveground biomass models improved when random effects modelling was applied and when ht as an additional predictor variable was considered (Tables 4 and 5). In model development, it is important that models are properly specified and that the structure of the data is taken into account. Our study illustrate that common model including ht generally performed well across study site, species, dbh, and ht classes by resulting into decline in MPE (\%) and that their corresponding random effects/species-specific further improved predictive accuracy (Table 5). This supports the role of random effects in explaining unexplained sources of variation which is only possible within the mixed modelling framework. In line with our results, Chave et al. (2005) reported that the inclusion of ht into a common mangrove biomass model reduced the standard error of aboveground biomass from 19.5 to $12.5 \%$ for mangrove trees, while other authors reported that random effects improved predictive power of biomass models for non-mangrove trees (e.g., $\mathrm{Fu}$ et al. 2014; Xu et al. 2014).

Despite models including ht being better, in most forest inventories, due to many reasons such as costs, trees are not frequently measured for ht. In such cases, users are obliged either to use models including dbh as the only predictor variable or initially estimate ht using relevant models and subsequently apply biomass models based on both dbh and ht as predictor variables. However, ht prediction models for mangroves are lacking in Tanzania and the rest of Africa.

Basic density (BD) is another predictor variable which could have potentially improved predictive accuracy particularly for the common biomass model (Komiyama et al. 2005; Chave et al. 2005). However, our models did not include BD as an additional predictor variable for two reasons; firstly, BD may vary between species and between species-specific tree components and between tree size. Therefore, applying BD determined based on comprehensive sampling in modelling tree biomass may improve model predictive accuracy. Since $\mathrm{BD}$ is never determined in forest inventories however and that no BD prediction models exist for mangrove species, such biomass models would be better yet with limited application. Secondly, for common biomass models, BD serves as species distinguishing factor whereby species mean $\mathrm{BD}$ values may be used as opposed to the use of species- and tree-specific BD values. The mixed modelling approach used in this study is robust in distinguishing species.

The tests of existing models on our data generally showed large and significant underpredictions for aboveground biomass (Table 7). The underpredictions were as large as $90 \%$ for some of the models (Kairo et al. 2009; Sitoe et al. 2014). Generally, predicted and observed biomass agreed quite well for small tree sizes, while the underpredictions increased with tree size (Fig. 5). Similar tests on belowground biomass for mangroves in Tanzania (Njana et al. 2015) showed prediction errors (underprediction) as high as $60 \%$ when models by Komiyama et al. (2005) (common model), Comley and McGuinness (2005) (species-specific model), and Kairo et al. (2009) (species-specific model) were applied. Plausible explanations for the observed prediction errors could be the application of the models beyond data ranges (size), geographical locations, and differences in forest structure and architecture. For the belowground biomass, an additional explanation could also be inadequate excavation procedures applied when some of these models were developed (see Njana et al. 2015). Any application of the already existing aboveand belowground biomass models to mangroves of Tanzania is therefore not recommended.

In the modelling, we applied species as random effects, which resulted into improved predictive accuracy of both the above- and the belowground biomass models, except for belowground biomass for $S$. alba where the models did not fit well to data (Table 4). This may be due to higher variances of BGB for this species (see Fig. 2). The contribution of random effects in improved predictive accuracy suggests that the biomass allometry varies by species. Therefore, the random effects/species-specific models should be applied since they are superior to the fixed effects/common models. For $S$. alba, however, the fixed effects model is recommended for belowground biomass. Since both the above- and the belowground biomass models performed fairly well across sites, the models may be applied across sites in Tanzania. However, the use of the models beyond species considered in this study is not recommended.

Aboveground tree component biomass estimates derived using models may be essential in describing forest structure (e.g., Camacho et al. 2011), determining forest productivity (e.g., Cox and Allen 1999; Kairo et al. 2008), and understanding ecosystem functions through quantification of carbon 
stocks and sequestration (e.g., Chen et al. 2012; Pandey and Pandey 2013) which are potentially relevant for climate change mitigation strategies. For example, the leaf biomass estimated from relevant models may provide useful information on nutrient cycling while the above- and belowground biomass models may be applied to generate tier 3 carbon stock estimates for carbon monitoring, reporting, and verification in REDD+ programs. The models may also be applied to the NAFORMA data for basic scientific ecological studies and for management decision-making. Since biomass estimates are essential for both ecological and management applications, the models (total AGB, BGB, and tree component models) from this study are expected to provide ecologists with the needed information and to support management of mangroves in Tanzania and elsewhere as deemed relevant. The aboveground tree component biomass models that we developed generally gave low prediction errors $(<10 \%)$ (Table 6). In addition, estimates based on tree components were additive (in agreement with the direct tree aboveground estimates). Therefore, we recommend the use of the developed aboveground tree component common models in deriving aboveground component-specific biomass estimates for utilization and ecological purposes, and the individual estimates may safely be added up.

\section{Conclusions}

The biomass models reported in this study are based on comprehensive data and modelling approach. The above- and belowground biomass models improved when random effects were considered. Therefore, random effects/species-specific models are generally recommended. For estimation of belowground biomass for $S$. alba however, the fixed effects/ common model is recommended. Based on our results, we discourage species-specific or site-specific model development for data entailing more than one species or site, instead we encourage the use of a mixed modelling approach which is robust for such data sets. The aboveground tree component biomass models may also be applied since they yield unbiased and additive estimates. Based on goodness of fit statistics, both the above- and the belowground biomass models developed in this study are the best available and provide an important tool for accurate estimation of biomass and carbon stock stored in mangrove forest in Tanzania for both management and ecological applications. Our models should be used within the range of data from which they were developed, and their use outside this data range should be done with caution.

Acknowledgments We thank the Tanzania Forest Service (TFS) field officers D. Mnyagi (Pangani), S. K. Nyabange (Bagamoyo), H. Mallya (Rufiji), and M. C. Mbago (Mtwara) for facilitation and logistical support during field work. We appreciate field assistants and the boat driver for their enthusiasm, hard work, courage, and encouragement during an intensive and risky fieldwork. The authors also would like to thank Tanzania Forest Service for permitting destructive sampling of mangrove trees for this study.

Funding We gratefully acknowledge financial support from the Climate Change Impacts and Adaptation Mitigation (CCIAM) Programme. The financial support from research projects, Impact of climate change on mangrove ecosystems and associated fishery resources along the Tanzanian coast and enhancing the Measuring, Reporting and Verification (MRV) of forests in Tanzania, is also appreciated. We are also indebted to CCIAM Programme for a PhD scholarship to the first author.

\section{References}

Brown S (1997) Estimating biomass change of tropical forests: primer, FAO Forestry Paper 134, Rome, Italy

Burnham KP, Anderson DR, Huyvaert KP (2011) AIC model selection and multi-model inference in behavioural ecology: some background, observations, and comparisons. Behav Ecol Sociol Biol 65:23-35

Camacho LD, Gevaña DT, Carandang AP, Camacho SC, Combalicer AE, Rebugio LL, Youn Y (2011) Tree biomass and carbon stock of a community-managed mangrove forest in Bohol, Philippines. For Sci Technol 7:161-167

Chai T, Draxler RR (2014) Root mean square error (RMSE) or mean absolute error (MAE)? - arguments against avoiding RMSE in the literature. Geosci Model Dev 7:1247-1250

Chave J, Andalo C, Brown S, Cairns MA, Chambers JQ, Eamus D, Fölster H, Fromard F, Higuchi N, Kira T, Lescure JP, Nelson B, Ogawa H, Puig H, Riéra B, Yamakura T (2005) Tree allometry and improved estimation of carbon stocks and balance in tropical forests. Oecologia 145:87-99

Chave J, Rejou-Mechain M, Burquez A, Chidumayo E, Colgan MS, Delitti WBC, Duque A, Eid T, Fearnside PM, Goodman RC, Henry M, Martinez-Yrizar A, Mugasha W, Muller-Landau HC, Mencuccini M, Nelson BW, Ngomanda A, Nogueira EM, Ortiz-Malavassi E, Pelissier R, Ploton P, Ryan CM, Saldarrriaga JG, Vieilledent (2014) Improved allometric models to estimate the aboveground biomass of tropical trees. Glob Chang Biol 10:3177-3190

Chen L, Zeng X, Tam NFY, Lu W, Luo Z, Du X, Wang J (2012) Comparing carbon sequestration and stand structure of monoculture and mixed mangrove plantations of Sonneratia caseolaris and S. apetala in Southern China. For Ecol Manag 284:222-229

Comley BWT, McGuinness KA (2005) Above- and below-ground biomass, and allometry of four common northern Australian mangroves. Aust J Bot 53:431-436

R Core Team (2014) R: a language and environment for statistical computing. R Foundation for Statistical Computing, Vienna, Austria. http://cran.r-project.org/bin/windows/base/ Accessed 20 Nov 2014

Cox EF, Allen JA (1999) Stand structure and productivity of the introduced Rhizophora mangle in Hawaii. Estuaries 22:276-284

de Miguel S, Pukkala T, Assaf N, Shater Z (2014) Intra-specific differences in allometric equations for aboveground biomass of Eastern Mediterranean Pinus brutia. Ann For Sci 71:101-112

Donato DC, Kauffman JB, Murdiyarso D, Kurnianto S, Stidham M, Kanninen M (2011) Mangroves among the most carbon-rich forests in the tropics. Nat Geosci 4:293-297

FAO (2007) The world's mangroves 1980-2005. FAO Forestry Paper 153, Rome, FAO

Fatoyinbo TE, Simard M, Washington-Allen RA, Shugart H (2008) Landscape-scale extent, height, biomass, and carbon estimation of 
Mozambique's mangrove forests with Landsat ETM+ and Shuttle Radar Topography Mission elevation data. Geophys Res 113:1-14

Fu L, Zeng W, Zhang H, Wang G, Lei Y, Tang S (2014) Generic linear mixed-effects individual-tree biomass models for Pinus massoniana in Southern China. South For 76:47-56

Harrell FE (2001) Regression modelling strategies: with application to linear models, logistic regression and survival analysis. Springer, New York

Hewson J, Steininger M, Pesmajoglou S (2013) REDD+ Measurement, Reporting and Verification (MRV) manual. USAID-supported forest carbon. Markets and Communities Program, Washington, DC

Husch B, Beers TW, Kershaw JA (2003) Forest mensuration, 4th edn. Wiley and Sons, Inc., Canada

IPCC (2003) IPCC good practice guidance for LULUCF. Institute for Global Environmental Strategies (IGES) for the IPCC. Kanagawa, Japan, p 590

IPCC (2006) Guidelines for national greenhouse gas inventories. IGES, Japan

IPCC (2007) Fourth assessment report: climate change 2007 (AR4) $<$ http://www.ipcc.ch/publications_and_data/publications_and data_reports.htm\#1>

Johnson JB, Omland KS (2004) Model selection in ecology and evolution. Trends Ecol Evol 19:101-108

Kairo JG, Lang'at JKS, Dahdouh-Guebas F, Bosire J, Karachi M (2008) Structural development and productivity of replanted mangrove plantations in Kenya. For Ecol Manag 255:2670-2677

Kairo JG, Bosire J, Langat J, Kirui B, Koedam N (2009) Allometry and biomass distribution in replanted mangrove plantations at Gazi Bay, Kenya. Aquat Conserv 19:S63-S69

Kauffman JB, Donato DC (2012) Protocols for the measurement, monitoring and reporting of structure, biomass and carbon stocks in mangrove forests. Working Paper 86. CIFOR, Bogor, Indonesia

Komiyama A, Poungparn S, Kato S (2005) Common allometric equations for estimating the tree weight of mangroves. J Trop Ecol 21:471-477

Komiyama A, Ong JE, Poungparn S (2008) Allometry, biomass, and productivity of mangrove forests: a review. Aquat Bot 89:128-137

Kuei CF (2008) Population structure, allometry and above-ground biomass of Avicennia marina forest at the Chishui River Estuary, Tainan County, Taiwan. J For Res 30:1-16

Li Y, Jiang L, Liu M (2011) A nonlinear mixed-effects model to predict stem cumulative biomass of standing trees. Procedia Environ Sci 10: 215-221

Lindstrom MJ, Bates DM (1990) Nonlinear mixed effects models for repeated measures data. Biometrics 46:673-687

Luoga EJ, Malimbwi RE, Kajembe GC, Zahabu E, Shemwetta DTK, Lyimo-Macha J, Mtakwa P, Mwaipopo CS (2004) Tree species composition and structures of Jasini Mwajuni Mangrove forest at Pangani, Tanzania. J TAF10:42-47

MNRT (Ministry of Natural Resources and Tourism) (1991) Management plan for the mangrove ecosystem of Rufiji District, mainland Tanzania, vol 7. Ministry of Tourism, Natural Resources and Environment (MTNRE), Forestry and Beekeeping Division, Catchment Forestry Project, Dar es Salaam

MNRT (Ministry of Natural Resources and Tourism) (2015) NAFORMA (National Forest Monitoring and Assessments of Tanzania) main results. Dar es Salaam

Mohamed MOS, Neukermans G, Kairo JG, Dahdouh-Guebas F, Koedam N (2009) Mangrove forests in a peri-urban setting: the case of Mombasa (Kenya). Wetl Ecol Manag 17:243-255

Moore JR (2010) Allometric equations to predict the total above-ground biomass of radiata pine trees. Ann For Sci 67:806-817

Mattia SB (1997) Species and structural composition of natural mangrove forests: a case study of the Rufiji delta, Tanzania. Dissertation for award of MSc. Degree at Sokoine University of Agriculture, Morogoro, Tanzania
Mugasha WA, Eid T, Bollandsås OM, Malimbwi RE, Chamshama SAO, Zahabu E, Katani JZ (2013) Allometric models for prediction of above- and belowground biomass of trees in the miombo woodlands of Tanzania. For Ecol Manag 310:87-101

Murray B, Pendleton L, Jenkins WA, Sifleet S (2011) Green payments for blue carbon economic incentives for protecting threatened coastal habitats, report NI 11 04. Institute for Environmental Policy Solutions, Nicholas

Njana MA, Eid T, Zahabu E, Malimbwi R (2015) Procedures for quantification of belowground biomass of three mangrove tree species. Wetl Ecol Manag 23:749-764

Nshare JS, Chitiki A, Malimbwi RE, Kinana BM, Zahabu E (2007) The current status of the mangrove forest along seashore at Salenda bridge, Dar es Salaam, Tanzania. J TAF 11:172-179

O'Hara RB, Kotze DJ (2010) Do not log-transform count data. Methods Ecol Evol 1:118-122

Packard GC (2009) On the use of logarithmic transformations in allometric analyses. J Theor Biol 257:515-518

Pandey CN, Pandey R (2013) Carbon sequestration by mangroves of Gujarat. India Int Jof Bot 3:57-70

Patil V, Singh A, Naik N, Unnikrishnan S (2014) Estimation of carbon stocks in Avicennia marina stand using allometry, CHN analysis, and GIS methods. Wetlands 34:379-391

Pinheiro J, Bates DM (1998) Model building for nonlinear mixed effects model. Department of Statistics University of Wisconsin, Madison

Pinheiro J, Bates D (2000) Mixed effects models in S and S-PLUS. Springer, New York

Pinheiro J, Bates D, DebRoy S, Sarkar D, R Core Team (2015) nlme: linear and nonlinear mixed effects models. R package version 3.1119, http://CRAN.R-project.org/package=nlme

Ray R, Ganguly D, Chowdhury C, Dey M, Das S, Dutta MK, Mandal SK, Majumder N, De TK, Mukhopadhyay JTK (2011) Carbon sequestration and annual increase of carbon stock in mangrove forest. Atmos Environ 45:5016-5024

Ritz C, Streibig JC (2008) Nonlinear regression with R. Springer, New York

Roxburgh SH, Paul KI, Clifford D, England JR, Raison RJ (2015) Guidelines for constructing allometric models for the prediction of woody biomass: how many individuals to harvest? Ecosphere 6:38 doi:10.1890/ES14-00251.1

Sileshi GW (2014) A critical review of forest biomass estimation models, common mistakes and corrective measures. For Ecol Manag 329: 237-254

Sitoe AA, Mandlate LJC, Guedes BS (2014) Biomass and carbon stocks of Sofala bay mangrove forests. Forests 5:1967-1981

Smith A, Granhus A, Astrup R, Bollandsås OM, Petersson H (2014) Functions for estimating aboveground biomass of birch in Norway. Scand J For Res 29:565-578

Tamai S, Nakasuga T, Tabuchi R, Ogino K (1986) Standing biomass of mangrove forests in Southern Thailand. J Jpn For Soc 68:384-388

Tamooh F, Huxhamd M, Karachi M, Mencuccini M, Kairo JG, Kirui B (2008) Below-ground root yield and distribution in natural and replanted mangrove forests at Gazi Bay, Kenya. For Ecol Manag 256:1290-1297

UNEP (United Nations Environment Programme) (2014) The importance of mangroves to people: a call to action. van Bochove, J., Sullivan, E., Nakamura, T. (Eds). United Nations Environment Programme World Conservation Monitoring Centre, Cambridge. $128 \mathrm{pp}$

URT (United Republic of Tanzania) (2002) The Forest Act No. 14. Forestry and Beekeeping Division, Ministry of Natural Resources and Tourism. Dar es Salaam, Tanzania. $281 \mathrm{pp}$

URT (United Republic of Tanzania) (2010) National Forest Resources Monitoring and Assessment of Tanzania (NAFORMA). Field manual. Biophysical survey. NAFORMA document M01-2010, p. 108

Vonesh EF, Chinchilli VM (1997) Linear and nonlinear models for the analysis of repeated measurements. Marcel Dekker, Inc., New York 
Walther BA, Moore JL (2005) The concepts of bias, precision and accuracy, and their use in testing the performance of species richness estimators, with a literature review of estimator performance. Ecography 28:815-829

Wang Y, Bonynge G, Nugranad J, Traber M, Ngusaru A, Tobey J, Hale L, Bowen R, Makota V (2003) Remote sensing of mangrove change along the Tanzania coast. Mar Geod 26:1-14

West BT, Welch KB, Gałecki AT (2007) Linear mixed models: a practical guide using statistical software. Taylor and Francis Group, LLC, New York
Xu H, Sun Y, Wang X, Fu Y, Dong Y (2014) Nonlinear mixed-effects (NLME) diameter growth models for individual China-fir (Cunninghamia lanceolata) trees in Southeast China. PLoS ONE 9:e104012. doi:10.1371/journal.pone.0104012

Zhou X, Brandle JR, Schoeneberger MM, Awada T (2007) Developing above-ground woody biomass equations for open-grown, multiplestemmed tree species: shelterbelt-grown Russian-olive. Ecol Model 202:311-323

Zuur A, Ieno EN, Walker NJ, Saveliev AA, Smith GM (2009) Mixed effects models and extensions in ecology with R. Springer, New York 